\title{
Reclassification of Saccharococcus caldoxylosilyticus as Geobacillus caldoxylosilyticus (Ahmad et al. 2000) comb. nov.
}

\footnotetext{
1 Department of Food Science and Microbiology - Industrial Microbiology Section, University of Milan, Sezione di Microbiologia Industriale, Via Celoria 2, 20133 Milan, Italy

2 DSMZ - German Collection of Microorganisms and Cell Cultures, 38124

Braunschweig, Germany
}

\author{
Maria Grazia Fortina, ${ }^{1}$ Diego Mora, ${ }^{1}$ Peter Schumann, ${ }^{2}$ Carlo Parini, ${ }^{1}$ \\ Pier Luigi Manachini ${ }^{1}$ and Erko Stackebrandt ${ }^{2}$
}

Author for correspondence: Maria Grazia Fortina. Tel: +39 258356692. Fax: + 39258356694 . e-mail: grazia.fortina@unimi.it

\begin{abstract}
A polyphasic study was performed on five thermophilic strains belonging to the genus Bacillus, isolated from soil of different geographical areas. 16S rRNA gene sequence analysis placed these isolates in RNA group 5, with Saccharococcus caldoxylosilyticus and [Bacillus] thermoglucosidasius being the closest phylogenetic neighbours. The type species of Saccharococcus, Saccharococcus thermophilus, was only moderately related to these two species and the novel isolates. DNA-DNA hybridization studies and comparison of morphological, chemotaxonomic and phenotypic features supported the close relationship between the novel isolates and Saccharococcus caldoxylosilyticus. These data justify the reclassification of Saccharococcus caldoxylosilyticus. Following the transfer of the validly described Bacillus species of group 5 into the genus Geobacillus, the reclassification of Saccharococcus caldoxylosilyticus as Geobacillus caldoxylosilyticus comb. nov. is proposed. This species can be distinguished genomically from Geobacillus thermoglucosidasius, Geobacillus stearothermophilus, Geobacillus thermodenitrificans and Saccharococcus thermophilus by a specific PCR-RFLP assay targeting the 16S rDNA.
\end{abstract}

Keywords: Geobacillus caldoxylosilyticus comb. nov., thermophilic bacteria, soil

\section{INTRODUCTION}

The first evidence that the genus Bacillus was phylogenetically heterogeneous and required extensive taxonomic revision goes back to 1991 (Ash et al., 1991), when the genus was divided into five phylogenetically distinct RNA groups. Three thermophilic species, Bacillus stearothermophilus, Bacillus kaustophilus and Bacillus thermoglucosidasius, constituted group 5. In subsequent studies (Rainey \& Stackebrandt, 1993; Rainey et al., 1994), other valid and invalid thermophilic Bacillus species, such as Bacillus thermoleovorans, 'Bacillus caldotenax', 'Bacillus caldovelox'

Abbreviations: ARDRA, amplified rDNA restriction analysis; RAPD, randomly amplified polymorphic DNA; RSA, ribosomal spacer analysis.

The EMBL accession numbers for the $16 \mathrm{~S}$ rDNA sequences of strains TS24A (= DSM 12833) and TS2A are AJ271738 and AJ271739. and 'Bacillus caldolyticus', and the spherical Saccharococcus thermophilus (Nystrand, 1984) were affiliated to group 5.

On the basis of phylogenetic evidence and supported by the availability of taxonomically salient characteristics, the genus Bacillus has been dissected into novel genera (Shida et al., 1996; Heyndrickx et al., 1998; Touzel et al., 2000; Fortina et al., 2001), new species have been described (Combet-Blanc et al., 1995; Pettersson et al., 1996; Heyndrickx et al., 1999) and invalid species have been validated (Sunna et al., 1997; Manachini et al., 2000). Only recently, Ahmad et al. (2000) described a new species of Saccharococcus, Saccharococcus caldoxylosilyticus. However, in contrast to the type species, the novel species exhibited a typical Bacillus-type morphology. Still more recent (Nazina et al., 2001) is the proposal of a new genus, Geobacillus, for the validated thermophilic Bacillus species of genetic group 5. 
In a previous work (Mora et al., 1998), we deepened some aspects of the taxonomic and genotypic diversity within the thermophilic Bacillus group 5 by the study of 85 novel isolates from different soil samples, using DNA-based fingerprinting methods such as amplified rDNA restriction analysis (ARDRA), randomly amplified polymorphic DNA (RAPD) fingerprints and ribosomal spacer analysis (RSA). The results of this study demonstrated the power of typing methods not only to group and identify successfully a major proportion of the thermophilic Bacillus isolates, but also to find strains belonging to novel genomovars of described species and novel species not yet described. In some cases, the number of novel strains was too small to provide a reliable description of the intraspecies variability, recommended for the characterization of a bacterial species defined by the polyphasic approach to taxonomy (Ursing et al., 1995; Vandamme et al., 1996).

In this study, we report the isolation and characterization of thermophilic bacilli from uncultivated soil of four different geographical areas, five of which shared high phenotypic, chemosystematic and genotypic similarities with the type strain of the recently described species Saccharococcus caldoxylosilyticus.

\section{METHODS}

Bacterial strains and isolation procedure. Isolates, their origin and reference organisms used are listed in Table 1. The new isolates were recovered from soil samples from different geographical areas through pasteurization at $90{ }^{\circ} \mathrm{C}$ for $10 \mathrm{~min}$ and subsequent growth on CESP agar [pH 7.2, containing $\left(1^{-1}\right): 15$ g casitone, 5 g yeast extract, 3 g soytone, $2 \mathrm{~g}$ peptone, $0.015 \mathrm{~g} \mathrm{MgSO}_{4}, 0.007 \mathrm{~g} \mathrm{FeCl}_{3}, 0.002 \mathrm{~g}$ $\mathrm{MnCl}_{2} \cdot \mathrm{H}_{2} \mathrm{O}$ ] at $65^{\circ} \mathrm{C}$ for $24 \mathrm{~h}$.

Strains were routinely maintained at $4{ }^{\circ} \mathrm{C}$ after growth at $55^{\circ} \mathrm{C}$ for $6-12 \mathrm{~h}$ on the same medium. Long-term preservation was achieved by suspending cells in broth cultures of the same medium supplemented with $15 \%$ glycerol and storing them at $-80^{\circ} \mathrm{C}$.

Morphological characteristics. The morphological life cycle was photographed in a phase-contrast microscope, by using cells grown on slides coated with a thin layer of CESP agar. Gram staining was done as described by Salle (1961). Colony characteristics were determined from 24-36 h cultures grown at $55^{\circ} \mathrm{C}$.

Phenotypic analysis. All assays were performed in triplicate and repeated when inconsistent results were obtained. The media and temperature used to determine physiological characteristics were as described above, unless stated otherwise.

The following characteristics were determined by the methods described by Smith et al. (1952): anaerobic growth in glucose broth, anaerobic production of gas from nitrate, citrate utilization, starch and casein hydrolysis and indole, acetoin and catalase production. Reduction of nitrate was examined using the method of Lanyi (1987) and the urease test followed the method described by Atlas (1993). Utilization of compounds as sole carbon sources was tested on agar plates containing $\left(1^{-1}\right) 1 \mathrm{~g}\left(\mathrm{NH}_{4}\right)_{2} \mathrm{HPO}_{4}, 0 \cdot 2 \mathrm{~g} \mathrm{KCl}, 0 \cdot 2 \mathrm{~g}$
Table 1. Strains used in this study

\begin{tabular}{|c|c|}
\hline Strain & Source \\
\hline \multicolumn{2}{|l|}{ Novel isolates } \\
\hline TS24A & Soil, Esna (Egypt) \\
\hline TS2A & Soil, Lingu (China) \\
\hline TS3B & Soil, Lingu (China) \\
\hline TS33B & Soil, Sassari (Italy) \\
\hline TSu3A & Soil, Denizli (Turkey) \\
\hline \multicolumn{2}{|l|}{ Reference strains } \\
\hline $\begin{array}{l}\text { Saccharococcus caldoxylosilyticus } \\
\text { DSM } 12041^{\mathrm{T}}\left(=\text { ATCC } 700356^{\mathrm{T}}\right)\end{array}$ & $\begin{array}{l}\text { Soil, Melbourne } \\
\text { (Australia)* }\end{array}$ \\
\hline \multicolumn{2}{|l|}{ Saccharococcus thermophilus } \\
\hline \multicolumn{2}{|l|}{ Geobacillus thermoglucosidasius } \\
\hline \multicolumn{2}{|l|}{ Geobacillus thermodenitrificans } \\
\hline \multicolumn{2}{|l|}{ Geobacillus thermocatenulatus } \\
\hline \multicolumn{2}{|l|}{ Geobacillus stearothermophilus $22^{\mathrm{T}}$} \\
\hline \multicolumn{2}{|l|}{ Geobacillus stearothermophilus T10 } \\
\hline \multicolumn{2}{|l|}{ Geobacillus thermoleovorans } \\
\hline \multicolumn{2}{|l|}{ Geobacillus kaustophilus } \\
\hline \multicolumn{2}{|l|}{ DSM $7363^{\mathrm{T}}$} \\
\hline \multicolumn{2}{|l|}{ 'Bacillus caldovelox' } \\
\hline \multicolumn{2}{|l|}{ DSM 411} \\
\hline \multicolumn{2}{|l|}{ 'Bacillus caldotenax' } \\
\hline \multicolumn{2}{|l|}{ DSM 406} \\
\hline \multicolumn{2}{|l|}{ 'Bacillus caldolyticus' } \\
\hline DSM 405 & \\
\hline
\end{tabular}

* Isolated by Ahmad et al. (2000).

$\mathrm{MgSO}_{4}, 0 \cdot 2 \mathrm{~g}$ yeast extract, $0.004 \mathrm{~g}$ bromocresol purple, $\mathrm{pH} 7$, supplemented with $0.5 \%(\mathrm{w} / \mathrm{v})$ of each carbon source, sterilized separately. The temperature range for growth was determined by observing growth at different temperatures over the range 40 to $75^{\circ} \mathrm{C}$ in a variable-temperature incubator (Politermomatic-Rossi); growth was recorded daily for up $4 \mathrm{~d}$. For $\mathrm{pH}$ studies, the $\mathrm{pH}$ of the medium was adjusted from 5 to 10 . Media were adjusted to the initial $\mathrm{pH}$ indicated with either $1 \mathrm{M} \mathrm{NaOH}$ or $1 \mathrm{M} \mathrm{HCl}$. Tolerance to salinity was determined in CESP broth supplemented with $2-10 \%(\mathrm{w} / \mathrm{v}) \mathrm{NaCl}$.

Cellular fatty acid composition. The analysis of fatty acid methyl ethers was performed by GLC as described by Schumann et al. (1997).

DNA base composition and DNA homology. DNA was isolated and purified as described previously (Manachini et al., 1985). The DNA base composition was determined by the thermal denaturation method described by Marmur \& Doty (1962) using the equation of Owen \& Hill (1979). DNA from Escherichia coli strain B (Sigma) was used as the internal standard.

DNA-DNA reassociation was determined by the optical renaturation rate method (Kurtzman et al., 1979) with a model Response spectrophotometer equipped with an Ad- 


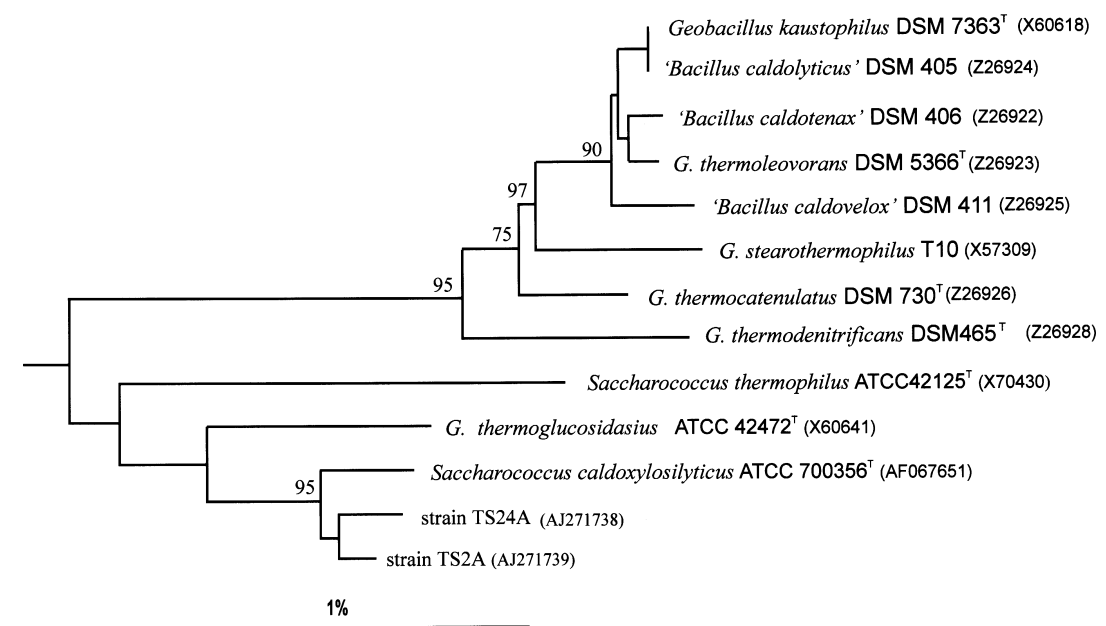

Fig. 1. $16 \mathrm{~S}$ rDNA sequence-based phylogenetic dendrogram constructed from evolutionary distances, showing the phylogenetic position of the strains tested, next to members of RNA group 5 of the thermophilic bacilli and related taxa. G., Geobacillus. Bar, $1 \%$ sequence similarity. vance Kinetics Graphic version 1.3 thermoprogrammer (Gilford system). For all samples tested, the melting temperature $\left(T_{\mathrm{m}}\right)$ was calculated in $5 \times \mathrm{SSC}$, the same salt concentration used for the determination of DNA-DNA homology. The temperature of hybridization was $25^{\circ} \mathrm{C}$ below the previously calculated $T_{\mathrm{m}}$. The equation of Seidler \& Mandel (1971) was used to calculate the extent of DNA-DNA reassociation.

16S rDNA sequence determination and phylogenetic analysis. Genomic DNA extraction, PCR-mediated amplification of the 16S rDNA and sequencing of the PCR products were performed as described previously (Rainey et al., 1994). The sequence reactions were electrophoresed using a model 373A automatic DNA sequencer (Applied Biosystems). The sequences obtained were aligned and compared with those of members of the thermophilic bacilli and a similarity matrix was obtained using the Ribosomal Database Project service (Maidak et al., 1999). Phylogenetic reconstructions were done using the algorithms of De Soete (1983), available in the Ribosomal Database Project, and of Saitou \& Nei (1987), which is part of the PHYLIP package (Felsenstein, 1993).

PCR-based techniques. For the PCR, $100 \mu$ of an overnight culture in CESP broth was added to $400 \mu 11 \times$ TE buffer (10 mM Tris $/ \mathrm{HCl}, 1 \mathrm{mM}$ disodium EDTA, $\mathrm{pH}$ 8) containing $0.45 \mathrm{mg}$ lysozyme $\mathrm{ml}^{-1}$. Following incubation for $30 \mathrm{~min}$ at $37^{\circ} \mathrm{C}$, SDS and proteinase $\mathrm{K}$ were added at final concentrations of $0.6 \%(\mathrm{w} / \mathrm{v})$ and $7 \mathrm{U} \mathrm{ml}^{-1}$. After incubation for $30 \mathrm{~min}$, the solution was extracted with an equal volume of phenol. The DNA was then precipitated by adding $0 \cdot 1$ vols sodium acetate and 2 vols $95 \%$ ethanol. The DNA pellet was air-dried and subsequently dissolved in $50 \mu \mathrm{l}$ sterilized water (HPLC grade).

ARDRA and RSA were performed as described previously (Mora et al., 1998).

The amplification of a region of $270 \mathrm{bp}$ encompassing part of the variable region $\mathrm{V} 4$ and part of $\mathrm{V} 3$ and ranging from positions 466 to 732 (E. coli sequence) was performed in $25 \mu \mathrm{l}$ containing $1 \mu \mathrm{l}$ bacterial genomic DNA solution obtained as above, $10 \mu 110 \times$ PCR buffer (Amersham Pharmacia Biotech), $200 \mu \mathrm{M}$ of each dNTP, $2.5 \mathrm{mM} \mathrm{MgCl}_{2}$, $0.5 \mathrm{U}$ Taq polymerase (Amersham) and $0.5 \mu \mathrm{M}$ of each of primers poll6SF (466, 5'-TCGAATAGGGCGGTACGG$\left.3^{\prime}\right)$ and pol16SR (732, 5'-GCCTTCGCCACTGGTGTT-3').
The temperature profile consisted of a primary DNA denaturation step at $94^{\circ} \mathrm{C}$ for 2 min followed by 30 cycles of $45 \mathrm{~s}$ at $94^{\circ} \mathrm{C}, 45 \mathrm{~s}$ at $60^{\circ} \mathrm{C}$ and $45 \mathrm{~s}$ at $72^{\circ} \mathrm{C}$. Following amplification, $5 \mu \mathrm{l}$ product was analysed by PAGE $(6 \%, 29$ : 1 acrylamide: bisacrylamide, TBE buffer). The gel was run at $5 \mathrm{~V} \mathrm{~cm}^{-1}$ in the appropriate buffer, stained in a solution containing $0.5 \mu \mathrm{g}$ ethidium bromide $\mathrm{ml}^{-1}$ and photographed under UV light. The $270 \mathrm{bp}$ amplified fragments were then digested for $1 \mathrm{~h}$ at $37^{\circ} \mathrm{C}$ in a $20 \mu \mathrm{l}$ reaction containing $7 \mu \mathrm{l}$ PCR product solution, $2 \mu$ incubation buffer and $5 \mathrm{U}$ HaeIII (Amersham). Restriction digests were subsequently analysed by PAGE as described above.

\section{RESULTS}

\section{$16 S$ rDNA sequence and phylogenetic analysis}

Almost complete $16 \mathrm{~S}$ rDNA sequences (1444 nt) were determined for isolates TS24A and TS2A. In both sequences, an ambiguity ( $\mathrm{Y}=\mathrm{C}$ or $\mathrm{T}$ ) was determined in the variable region $\mathrm{V} 4$ at position 633 of the $E$. coli sequence (Winker \& Woese, 1991). Comparison of these $16 \mathrm{~S}$ rDNA sequences (binary similarity of $99.9 \%$ ) with those of several thermophilic bacilli and the two Saccharococcus species revealed a high phylogenetic similarity of strains TS24A and TS2A to $S$. caldoxylosilyticus DSM 12041 ${ }^{\mathrm{T}}(99 \cdot 6 \%)$. A bootstrap value of $95 \%$ supported the clustering of these three organisms found by the two distance-matrix algorithms applied. The dendrogram obtained using the algorithm of De Soete (1983) is depicted in Fig. 1. The closest phylogenetic neighbour of these strains was Geobacillus (formerly Bacillus) thermoglucosidasius, followed by $S$. thermophilus. Lower similarities were found to Geobacillus thermodenitrificans, Geobacillus stearothermophilus and Geobacillus thermoleovorans.

\section{Morphology and biochemical properties}

Cells of all strains isolated from soil samples were motile, Gram-positive, catalase-positive and rodshaped, varying in length from 4 to $6 \mu \mathrm{m}$ and $0 \cdot 5-1 \mu \mathrm{m}$ in diameter, normally present as single cells or in short chains. Oval spores were located terminally within a 


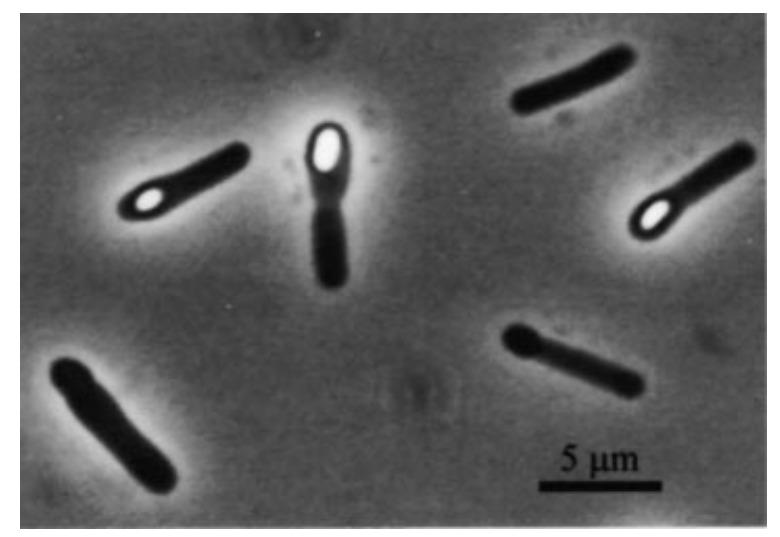

Fig. 2. Phase-contrast micrograph of Geobacillus caldoxylosilyticus strain TS24A grown at $55^{\circ} \mathrm{C}$ on CESP agar. Bar, $5 \mu \mathrm{m}$.

swollen sporangium (Fig. 2). Colonies exhibited a regular, flat morphology with entire margins and were off-white to beige. All the isolates grew optimally between 50 and $65^{\circ} \mathrm{C}$. No growth was observed below $42{ }^{\circ} \mathrm{C}$ and some strains showed weak growth at $45^{\circ} \mathrm{C}$. All strains showed a maximum temperature for growth of $70{ }^{\circ} \mathrm{C}$ and did not grow at $\mathrm{pH} 5$ or 11 ; strains TSu3A and TS33B were able to grow at $\mathrm{pH} 9$. No growth was detected in the presence of $3 \% \mathrm{NaCl}$. The isolates reduced nitrate to nitrite and strains TS2A, TS24A and TS33B also showed the ability to reduce nitrite to gas. The strains used a wide variety of carbon sources when grown aerobically. The following compounds were assimilated within 24-36 h: glucose, maltose, trehalose, lactose, galactose and cellobiose. Fructose, sucrose, arabinose, ribose and xylose were assimilated within $48-56 \mathrm{~h}$, whereas utilization of rhamnose was variable within the species. The new isolates could be also characterized phenotypically on the basis of their ability to use citrate as a sole carbon source. Starch and casein were hydrolysed.

Anaerobic production of gas from nitrate and anaerobic growth in glucose broth were weak. All strains were negative for indole and urease production and for the Voges-Proskauer test (acetylmethylcarbinol production).

Comparison of phenotypic data for the soil isolates with those of some related reference strains (Table 2) showed a pattern similar to that of $S$. caldoxylosilyticus DSM $12041^{\mathrm{T}}$, while those of the other reference strains were distinctly different. The only slight differences in the reactions of strain DSM $12041^{\mathrm{T}}$ and the soil isolates were the ability of the former strain to grow better under anaerobic conditions and to utilize citrate poorly only. Other characteristics that were not investigated originally, such as nitrate reduction and casein and urea hydrolysis, were similar to those obtained for the soil isolates. Comparison with the phylogenetically nearest species, G. thermoglucosidasius DSM $2542^{\mathrm{T}}$, indicated that the new isolates

Table 2. Phenotypic characteristics of soil isolates and some related thermophilic bacilli

Taxa are identified as: 1, S. caldoxylosilyticus; 2, S. thermophilus; 3, G. thermoglucosidasius; 4, G. stearothermophilus; 5, G. thermodenitrificans. Characters are scored as: +, positive; -, negative; w, weak reaction; ND, not determined (data obtained in our laboratory are shown in parentheses); v, variable within the group. Data were obtained from this study or from Ahmad et al. (2000) (S. caldoxylosilyticus), Nystrand (1984) (S. thermophilus), Suzuki et al. (1983) (G. thermoglucosidasius), Logan \& Berkeley (1984) and Claus \& Berkeley (1986) (G. stearothermophilus) and Manachini et al. (2000) (G. thermodenitrificans). All isolates and reference strains were positive for the Gram reaction, catalase and utilization of glucose, fructose, maltose, trehalose, mannose and sucrose. They were all negative for indole production and the Voges-Proskauer test.

\begin{tabular}{|c|c|c|c|c|c|c|}
\hline Phenotypic trait & Soil isolates & 1 & 2 & 3 & 4 & 5 \\
\hline Cell morphology & Rods & Rods & Cocci/irregular clusters & Rods & Rods & Rods \\
\hline Spore formation & + & + & - & + & + & + \\
\hline Growth in the presence of $3 \% \mathrm{NaCl}$ & - & - & ND & - & $\mathrm{V}$ & + \\
\hline Starch hydrolysis & + & + & - & + & + & $\mathrm{W}$ \\
\hline Casein hydrolysis & + & $\mathrm{ND}(+)$ & ND & + & $\mathrm{V}$ & + \\
\hline Citrate (Simmons') & + & W & - & - & - & - \\
\hline Anaerobic growth & w & + & - & - & - & + \\
\hline \multicolumn{7}{|l|}{ Reduction of: } \\
\hline $\mathrm{NO}_{3}^{-}$to $\mathrm{NO}_{2}^{-}$ & + & ND $(+)$ & $\mathrm{V}$ & + & $\mathrm{V}$ & + \\
\hline $\mathrm{NO}_{2}^{-}$to gas & $\mathrm{V}$ & ND & - & - & - & + \\
\hline Urease & - & $\mathrm{ND}(-)$ & - & + & - & - \\
\hline \multicolumn{7}{|l|}{ Utilization of: } \\
\hline Rhamnose & $\mathrm{V}$ & + & + & + & - & - \\
\hline Lactose & + & + & - & - & $\mathrm{V}$ & + \\
\hline Galactose & + & + & + & - & $\mathrm{V}$ & + \\
\hline Xylose & + & + & + & + & - & + \\
\hline Arabinose & + & + & + & - & - & + \\
\hline
\end{tabular}


Table 3. Cellular fatty acid compositions of soil isolates and some related thermophilic bacilli

Values are percentages of total fatty acids. -, Not detected. Taxa are identified as: 1 , strain TS24A; 2, strain TS2A; 3, S. caldoxylosilyticus DSM $12041^{\mathrm{T}} ; 4$, S. thermophilus DSM $4749^{\mathrm{T}} ; 5$, G. thermoglucosidasius DSM 2542 ${ }^{\mathrm{T}} ; 6, G$. thermodenitrificans DSM 465 $; 7$, G. stearothermophilus DSM $22^{\mathrm{T}}$. Abbreviations for fatty acids are illustrated by the following examples: $\mathrm{C}_{16: 0}$, hexadecanoic acid; $\mathrm{i}-\mathrm{C}_{15: 0}, 13-$ methyl tetradecanoic acid; ai- $\mathrm{C}_{17: 0}, 14$-methyl hexadecanoic acid.

\begin{tabular}{|lrrrrrrr|}
\hline Fatty acid & $\mathbf{1}$ & $\mathbf{2}$ & $\mathbf{3}$ & $\mathbf{4}$ & $\mathbf{5}$ & $\mathbf{6}$ & $\mathbf{7}$ \\
\hline $\mathrm{C}_{14: 0}$ & $0 \cdot 5$ & $1 \cdot 1$ & - & $1 \cdot 7$ & $1 \cdot 0$ & - & $0 \cdot 6$ \\
i-C $_{15: 0}$ & $51 \cdot 3$ & $45 \cdot 8$ & $56 \cdot 7$ & $58 \cdot 5$ & $22 \cdot 8$ & $40 \cdot 0$ & $34 \cdot 8$ \\
ai-C $_{15: 0}$ & $1 \cdot 6$ & $1 \cdot 7$ & $1 \cdot 1$ & $2 \cdot 1$ & $1 \cdot 9$ & $1 \cdot 3$ & $4 \cdot 4$ \\
$\mathrm{C}_{15: 0}$ & $1 \cdot 3$ & $2 \cdot 2$ & $1 \cdot 7$ & - & $2 \cdot 8$ & $1 \cdot 4$ & - \\
i-C & $4 \cdot 3: 0$ & $6 \cdot 1$ & $6 \cdot 8$ & $1 \cdot 1$ & $15 \cdot 1$ & $7 \cdot 2$ & $5 \cdot 9$ \\
$\mathrm{C}_{16: 0}$ & $2 \cdot 3$ & $7 \cdot 5$ & $2 \cdot 2$ & $13 \cdot 5$ & $17 \cdot 1$ & $5 \cdot 8$ & $14 \cdot 5$ \\
i-C $_{17: 0}$ & $30 \cdot 3$ & $28 \cdot 9$ & $26 \cdot 7$ & $20 \cdot 3$ & $26 \cdot 3$ & $33 \cdot 8$ & $23 \cdot 5$ \\
ai-C $_{17: 0}$ & $3 \cdot 7$ & $5 \cdot 2$ & $2 \cdot 5$ & $2 \cdot 8$ & $10 \cdot 1$ & $6 \cdot 1$ & $15 \cdot 3$ \\
$\mathrm{C}_{17: 0}$ & - & - & - & - & $1 \cdot 7$ & $1 \cdot 2$ & - \\
i-C $_{17: 1}$ & $1 \cdot 2$ & $1 \cdot 6$ & $2 \cdot 3$ & - & - & $1 \cdot 9$ & - \\
$\mathrm{C}_{18: 0}$ & - & - & - & - & $0 \cdot 9$ & - & - \\
\hline
\end{tabular}

could be distinguished easily phenotypically on the basis of urease production and the utilization of citrate, lactose, galactose and arabinose.

\section{Cellular fatty acid composition}

The cellular fatty acid profiles of strains TS24A and TS2A were characterized by the prevalence of $\mathrm{i}-\mathrm{C}_{15: 0}$ $(45 \cdot 8-48 \cdot 9 \%)$ and $\mathrm{i}-\mathrm{C}_{17: 0}(28 \cdot 9-29 \cdot 1 \%)$, with minor amounts of $\mathrm{i}-\mathrm{C}_{16: 0}, \mathrm{C}_{16: 0}$ and ai- $\mathrm{C}_{17: 0}$ (Table 3). $S$. caldoxylosilyticus DSM $12041^{\mathrm{T}}$ showed a similar profile. On the basis of fatty acid composition, the isolates could not be differentiated from G. thermodenitrificans DSM $465^{\mathrm{T}}$ or G. stearothermophilus DSM $22^{\mathrm{T}}$, but they were easily distinguishable from their closest phylogenetic neighbour, G. thermoglucosidasius. The main differences were the smaller amount of $\mathrm{i}-\mathrm{C}_{15: 0}(22.8 \%)$ and the larger amounts of i- $\mathrm{C}_{16: 0}(15 \cdot 1 \%), \mathrm{C}_{16: 0}(17 \cdot 1 \%)$ and ai- $\mathrm{C}_{17: 0}(10 \cdot 1 \%)$ in G. thermoglucosidasius DSM $2542^{\mathrm{T}}$. S. thermophilus DSM $4749^{\mathrm{T}}$ showed an intermediate position between the soil isolates and $S$. caldoxylosilyticus and $G$. thermoglucosidasius, with the $\mathrm{i}-\mathrm{C}_{15: 0}$ and ai- $\mathrm{C}_{17: 0}$ contents similar to those of our isolates and a large amount of $\mathrm{C}_{16: 0}$, as in $G$. thermoglucosidasius. Another feature that distinguished $S$. thermophilus from the other reference strains was the low content of $\mathrm{i}-\mathrm{C}_{16: 0}$.

\section{DNA base compositions and DNA homology}

The levels of DNA-DNA homology and the $\mathrm{G}+\mathrm{C}$ contents of the strains are shown in Table 4. Using DNA of strain TS24A as a reference, all the soil isolates belonged to the same homology group, with high levels of DNA relatedness, ranging from 84 to $99 \%$. Low similarities only were found to the phylogenetically related G. thermoglucosidasius DSM $2542^{\mathrm{T}}$, G. thermodenitrificans DSM $465^{\mathrm{T}}$ and G. stearothermophilus DSM $22^{\mathrm{T}}$. S. thermophilus and $S$. caldoxylosilyticus revealed a reassociation of $35 \%$, which is significantly lower than the value reported by Ahmad et al. (2000) (67\%). These data showed that the new isolates, together with $S$. caldoxylosilyticus, represent a novel, genomically homogeneous taxon, well differentiated from the other three related species.

The DNA $\mathrm{G}+\mathrm{C}$ content of the novel isolates ranged from $44 \cdot 0$ to $50 \cdot 2 \mathrm{~mol} \%$.

Table 4. DNA base composition and DNA relatedness among thermophilic soil isolates and phylogenetically closely related thermophilic bacteria

Reassociation values are means of three determinations; the maximum difference noted between determinations was $7 \%$. Values in parentheses indicate that, by definition, the reassociation value was $100 \%$.

\begin{tabular}{|c|c|c|c|c|c|c|c|}
\hline \multirow[t]{2}{*}{ Strain } & \multirow[t]{2}{*}{$\mathrm{G}+\mathrm{C}$ content $(\mathrm{mol} \%)$} & \multicolumn{6}{|c|}{ DNA-DNA hybridization (\%) with: } \\
\hline & & 1 & 6 & 7 & 8 & 9 & 10 \\
\hline 1. TS24A & $47 \cdot 4$ & (100) & & & & & \\
\hline 2. TS2A & $44 \cdot 0$ & 99 & & & & & \\
\hline 3. TS3B & $46 \cdot 1$ & 86 & & & & & \\
\hline 4. TS33B & $44 \cdot 0$ & 84 & & & & & \\
\hline 5. TSu3A & $50 \cdot 2$ & 91 & & & & & \\
\hline 6. S. caldoxylosilyticus DSM $12041^{\mathrm{T}}$ & $45 \cdot 8$ & 89 & (100) & & & & \\
\hline 7. S. thermophilus DSM $4749^{\mathrm{T}}$ & $47 \cdot 6$ & 51 & 35 & $(100)$ & & & \\
\hline 8. G. thermoglucosidasius DSM $2542^{\mathrm{T}}$ & $45 \cdot 9$ & 2 & 39 & 23 & $(100)$ & & \\
\hline 9. G. thermodenitrificans DSM $465^{\mathrm{T}}$ & $50 \cdot 3$ & 7 & & & 28 & $(100)$ & \\
\hline 10. G. stearothermophilus DSM $22^{\mathrm{T}}$ & $52 \cdot 0$ & 2 & & & & 43 & $(100)$ \\
\hline
\end{tabular}




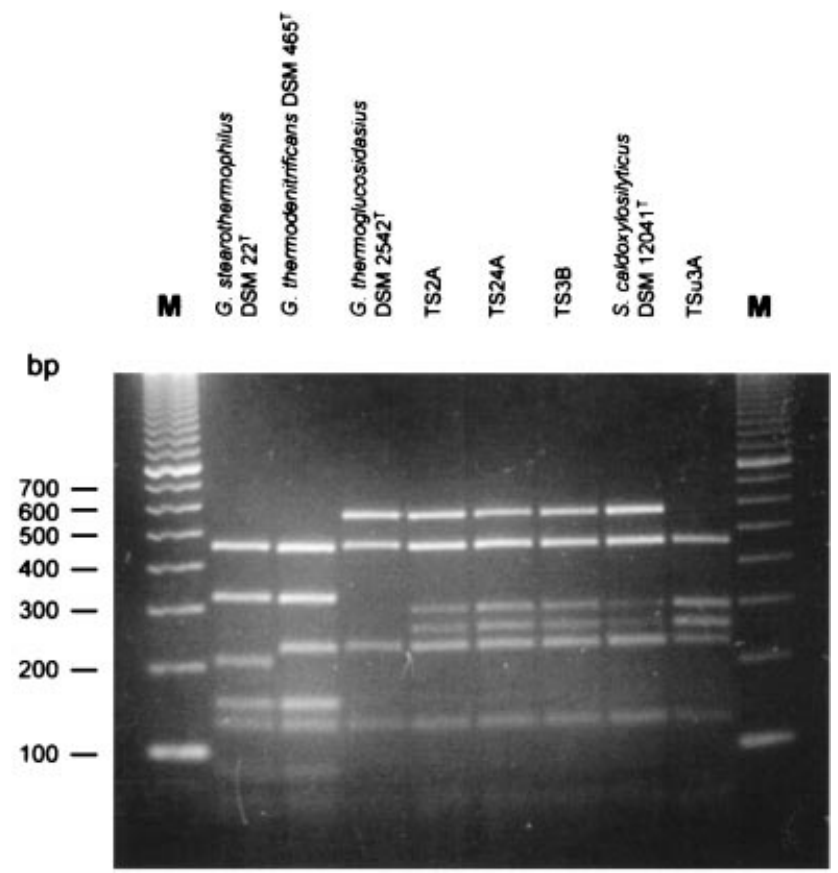

Fig. 3. ARDRA patterns obtained from soil isolates and some related thermophilic species. Lanes $M, 100 \mathrm{bp}$ ladder DNA molecular mass marker (Amersham-Pharmacia).

\section{ARDRA}

HaeIII analysis showed that all soil isolates (isolate TS33B not shown) and S. caldoxylosilyticus showed a common pattern, which was composed of restriction fragments of about 125, 235, 270, 300 and $450 \mathrm{bp}$ (Fig. 3 ). With the exception of strain TSu3A, all of the soil isolates and $S$. caldoxylosilyticus were also characterized by an additional fragment of $570 \mathrm{bp}$. In these strains, the number of nucleotides calculated for the HaeIII fragments was greater than the size of the 16S rRNA (about $1540 \mathrm{bp}$ ). The reason for the larger sum could be the presence of multiple rDNA alleles within a single genome. This can be verified by the ambiguity at position 633 detected by sequencing of the $16 \mathrm{~S}$ rDNA ( $\mathrm{Y}=\mathrm{C}$ or $\mathrm{T}$; see above). Indeed, the presence of $\mathrm{C}$ at position 633 in one allele generates an additional HaeIII site of size 570 bp that increased the number of restriction fragments produced by the enzymic restriction.

G. thermoglucosidasius DSM $2542^{\mathrm{T}}$ showed the most similar pattern to the soil isolates, sharing the 125,235 , 450 and $570 \mathrm{bp}$ fragments. This is in accord with the $16 \mathrm{~S}$ rDNA analysis.

\section{PCR assay and restriction analysis}

Two PCR primers, pol16SF and pol16SR (see Methods), were selected upstream and downstream of position 633 in order to generate a PCR fragment of $270 \mathrm{bp}$ in which the unique HaeIII site should result
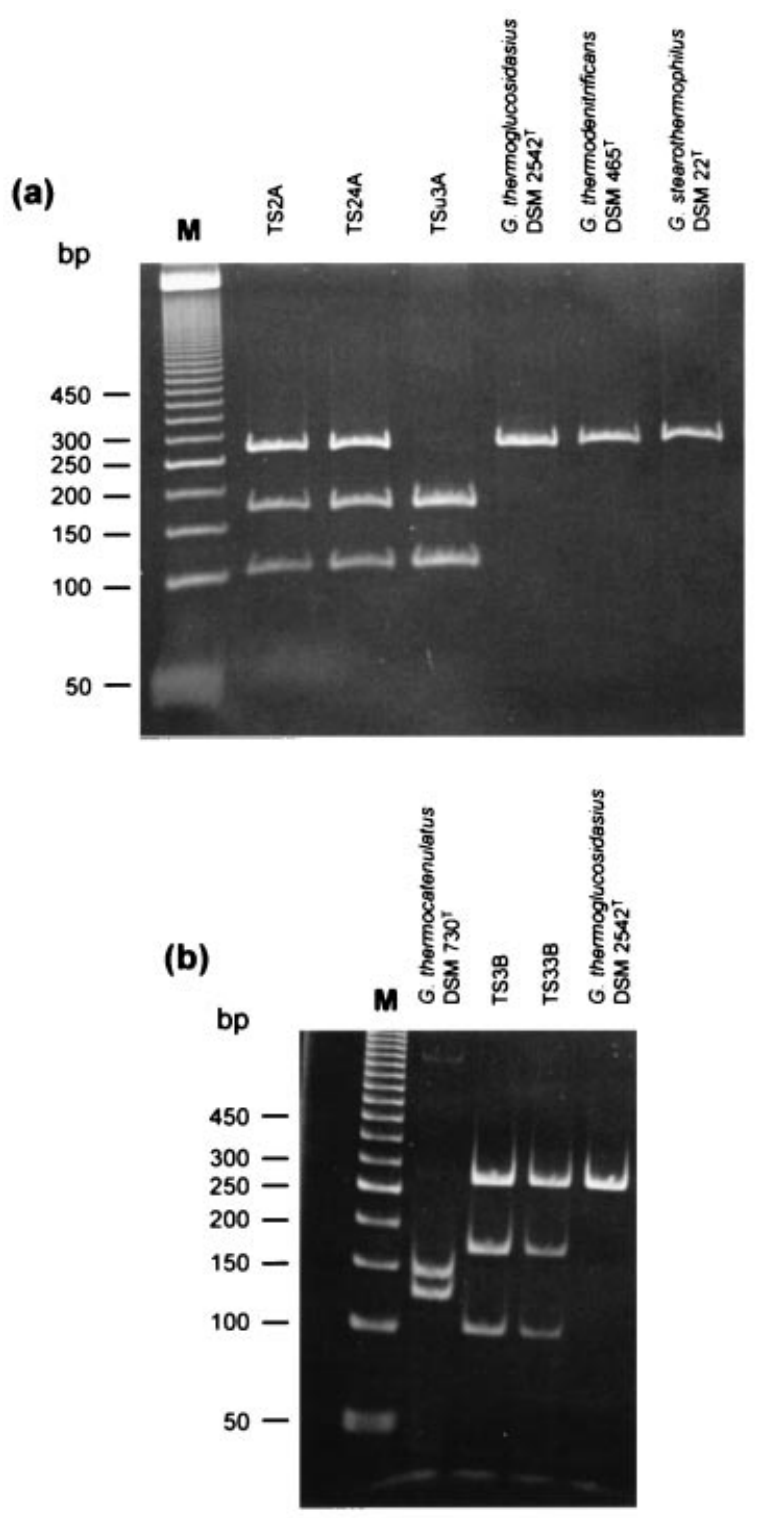

Fig. 4. Polyacrylamide gels showing the Haell restriction profiles of a $270 \mathrm{bp}$ fragment encompassing position 633 ( $E$. coli sequence) of the 16S rDNA of the soil isolates and some phylogenetically related thermophilic bacilli. Lanes $M, 50 \mathrm{bp}$ ladder DNA molecular mass marker (Amersham-Pharmacia).

from the presence of $\mathrm{C}$ at position 633 . The subsequent restriction analysis of the $270 \mathrm{bp}$ amplified fragments confirmed the presence of two main 16S rDNA alleles (presence of both $\mathrm{C}$ and $\mathrm{T}$ residues at position 633) in strains TS24A, TS2A, TS3B and TS33B (Fig. 4) and S. caldoxylosilyticus, since both the expected digested products of 170 and $100 \mathrm{bp}$ and the non-digested $270 \mathrm{bp}$ fragment were present (Fig. 4). Strain TSu3A showed only two smaller fragments, confirming the ARDRA pattern (Fig. 3), and thus corroborating the hypothesis of the presence of only one type of $16 \mathrm{~S}$ rDNA as the main chromosomal allele, containing the 


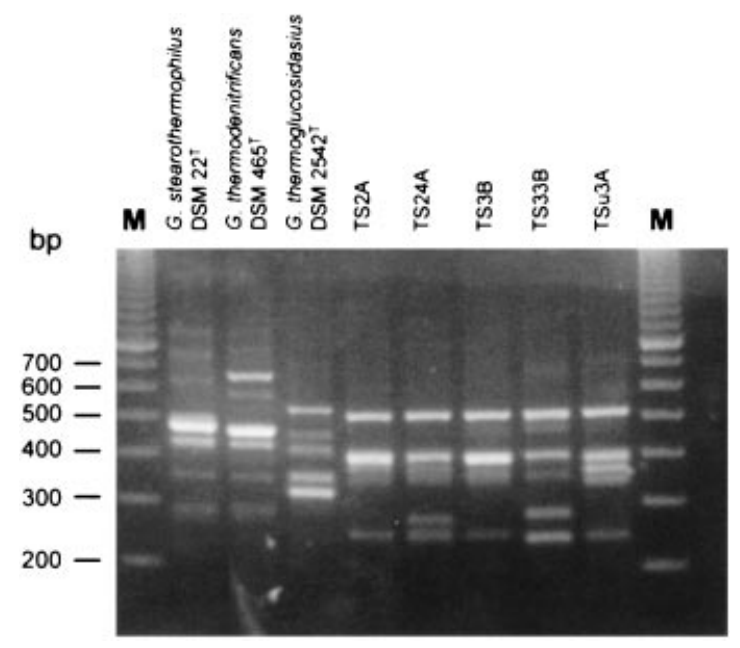

Fig. 5. RSA patterns obtained from soil isolates and some related thermophilic species. Lanes $M, 100 \mathrm{bp}$ ladder DNA molecular mass marker (Amersham-Pharmacia).

$\mathrm{C}$ residue at position 633 . The $270 \mathrm{bp}$ amplified fragments from the other thermophilic Geobacillus species were not digested or generated different restriction profiles, as was the case for Geobacillus thermocatenulatus DSM $730^{\mathrm{T}}$ (Fig. 4b).

\section{RSA}

Amplification of the internal transcribed spacer between the 16S and 23S rDNA is shown in Fig. 5. The soil isolates could be distinguished from the reference strains by the presence of three common main amplification fragments, of about 240, 400 and $510 \mathrm{bp}$. Amplification products ranging from approximately 270 to $370 \mathrm{bp}$ permitted discrimination of some of the isolates (TS33B, TSu3A). As observed previously (Mora et al., 1998), G. stearothermophilus DSM $22^{\mathrm{T}}$, G. thermodenitrificans DSM $465^{\mathrm{T}}$ and G. thermoglucosidasius DSM $2542^{\mathrm{T}}$ showed distinctive amplification profiles that were typical of each strain analysed.

\section{DISCUSSION}

Initial studies on five thermophilic strains isolated from uncultivated soils of four different geographical areas showed these new isolates to represent a novel, genetically homogeneous taxon within the genus $\mathrm{Ba}$ cillus. Based upon phylogenetic, morphological and biochemical evidence, this new taxon is clearly a member of RNA group 5 (Ash et al., 1991), the closest relative being $[B$.$] thermoglucosidasius. Whilst this$ study was underway, a novel species of Saccharococcus, S. caldoxylosilyticus, was described (Ahmad et al., 2000). In the phylogenetic analysis of the original description of this species (Ahmad et al., 2000), which is spore-forming and rod-shaped but not spherical, the species $[B$.] thermoglucosidasius was not included, and the new species consequently grouped adjacent to $S$. thermophilus. This omission most likely led to the misclassification of this thermophilic and xylosedegrading species.

The inclusion of the five novel isolates not only led to a correction of the phylogenetic position of $S$. caldoxylosilyticus but also revealed that these new isolates had to be considered members of this species, with which they shared high DNA-DNA relatedness, phenotypic and morphological properties and molecular similarities, as revealed by ARDRA analysis using HaeIII and a specific PCR-RFLP assay targeted to the 16S rDNA. These properties also distinguished $S$. caldoxylosilyticus and the soil isolates from the other thermophilic species of RNA group 5.

Recently, on the basis of phylogenetic and fatty acid analyses, the validly described Bacillus species of group 5 have been transferred to a new genus, Geobacillus. On the basis of the evidence mentioned above, which is based on properties used conventionally to affiliate species to a genus, such as phylogenetic position and morphology, we therefore propose to reclassify Saccharococcus caldoxylosilyticus as a member of genus Geobacillus, the generic affiliation of its closest phylogenetic neighbour, G. thermoglucosidasius. The International Code of Nomenclature of Bacteria (Lapage et al., 1992) requires that, in a new combination, the type strain of the reclassified species is maintained as the type strain.

\section{Description of Geobacillus caldoxylosilyticus (Ahmad et al. 2000) comb. nov.}

Geobacillus caldoxylosilyticus (cal.do.xy.lo.si.ly'ti.cus. L. adj. caldus hot; N.L. neut. n. xylosum xylose; N.L. adj. lyticus dissolving, degrading; caldoxylosilyticus hot and xylose-degrading).

The description includes elements of the original description of Ahmad et al. (2000) and properties determined in this study. Gram-positive, catalasepositive rods, varying in length from 4 to $6 \mu \mathrm{m}$ and $0 \cdot 5-1 \mu \mathrm{m}$ in diameter, normally present as single cells or in short chains. Oval spores are located terminally within a swollen sporangium. The optimal growth temperature ranges between 50 and $65^{\circ} \mathrm{C}$ with a minimum at $42{ }^{\circ} \mathrm{C}$ and a maximum at $70^{\circ} \mathrm{C}$. Nitrate reduction is positive. Anaerobic production of gas from nitrate. Acid production from glucose, fructose, sucrose, maltose, trehalose, lactose, galactose, cellobiose, arabinose, ribose and xylose. Starch and casein are hydrolysed. Strains vary in their utilization of rhamnose and citrate. All strains are negative for indole and urease production, the Voges-Proskauer test (acetylmethylcarbinol production) and anaerobic growth. The main cellular fatty acids are $\mathrm{i}-\mathrm{C}_{15: 0}$ and i- $\mathrm{C}_{17: 0}$. Phylogenetically, a member of RNA group 5 of Geobacillus. The DNA G $+\mathrm{C}$ content ranges from $44 \cdot 0$ to $50 \cdot 2 \mathrm{~mol} \%$. Habitat, soil.

The type strain is DSM $12041^{\mathrm{T}}$ (= ATCC $700356^{\mathrm{T}}$ ). 


\section{REFERENCES}

Ahmad, S., Scopes, R. K., Rees, G. N. \& Patel, B. K. C. (2000). Saccharococcus caldoxylosilyticus sp. nov., an obligately thermophilic, xylose-utilizing, endospore-forming bacterium. Int J Syst Evol Microbiol 50, 517-523.

Ash, C., Farrow, J. A. E., Wallbanks, S. \& Collins, M. D. (1991). Phylogenetic heterogeneity of the genus Bacillus revealed by comparative analysis of small-subunit ribosomal RNA sequences. Lett Appl Microbiol 13, 202-206.

Atlas, R. M. (1993). Handbook of Microbiological Media, p. 967. Edited by L. C. Park. London: CRC Press.

Claus, D. \& Berkeley, R. C. W. (1986). Genus Bacillus Cohn 1872. In Bergey's Manual of Systematic Bacteriology, vol. 2, pp. 1105-1139. Edited by P. H. A. Sneath, N. S. Mair, M. E. Sharpe \& J. G. Holt. Baltimore: Williams \& Wilkins.

Combet-Blanc, Y., Ollivier, B., Streicher, C., Patel, B. K. C., Dwivedi, P. P., Pot, B., Prensier, G. \& Garcia, J.-L. (1995). Bacillus thermoamylovorans sp. nov., a moderately thermophilic and amylolytic bacterium. Int $J$ Syst Bacteriol 45, 9-16.

De Soete, G. (1983). A least squares algorithm for fitting additive trees to proximity data. Psychometrika 48, 621-626.

Felsenstein, J. (1993). PHYLIP (Phylogeny Inference Package), version 3.5c. Distributed by the author. Department of Genetics, University of Washington, Seattle, USA.

Fortina, M. G., Pukall, R., Schumann, P., Mora, D., Parini, C., Manachini, P. L. \& Stackebrandt, E. (2001). Ureibacillus gen. nov., a new genus to accommodate Bacillus thermosphaericus (Andersson et al. 1995), emendation of Ureibacillus thermosphaericus and description of Ureibacillus terrenus sp. nov. Int $J$ Syst Evol Microbiol 51, 447-455.

Heyndrickx, M., Lebbe, L., Kersters, K., De Vos, P., Forsyth, G. \& Logan, N. A. (1998). Virgibacillus: a new genus to accommodate Bacillus pantothenticus (Proom and Knight 1950). Emended description of Virgibacillus pantothenticus. Int J Syst Bacteriol 48, 99-106.

Heyndrickx, M., Lebbe, L., Kersters, K., Hoste, B., De Wachter, R., De Vos, P., Forsyth, G. \& Logan, N. A. (1999). Proposal of Virgibacillus proomii sp. nov. and emended description of Virgibacillus pantothenticus (Proom and Knight 1950) Heyndrickx et al. 1998. Int J Syst Bacteriol 49, 1083-1090.

Kurtzman, C. P., Johnson, C. J. \& Smiley, M. J. (1979). Determination of conspecificity of Candida utilis and Hansenula jadinii through DNA reassociation. Mycologia 71, 844-847.

Lanyi, B. (1987). Classical and rapid identification: methods for medically important bacteria. Methods Microbiol 19, 1-67.

Lapage, S. P., Sneath, P. H. A., Lessel, E. F., Skerman, V. B. D., Seeliger, H. P. R. \& Clark, W. A. (editors) (1992). International Code of Nomenclature of Bacteria (1990 Revision). Bacteriological Code. Washington, DC: American Society for Microbiology.

Logan, N. A. \& Berkeley, R. C. W. (1984). Identification of Bacillus strains using the API system. J Gen Microbiol 130, 1871-1882.

Maidak, B. L., Cole, J. R., Parker, C. T., Jr \& 11 other authors (1999). A new version of the RDP (Ribosomal Database Project). Nucleic Acids Res 27, 171-173.

Manachini, P. L., Fortina, M. G., Parini, C. \& Craveri, R. (1985). Bacillus thermoruber sp. nov., nom. rev., a red-pigmented thermophilic bacterium. Int J Syst Bacteriol 35, 493-496.

Manachini, P. L., Mora, D., Nicastro, G., Parini, C., Stackebrandt, E., Pukall, R. \& Fortina, M. G. (2000). Bacillus thermodenitrificans sp. nov., nom. rev. Int J Syst Evol Microbiol 50, 1331-1337.
Marmur, J. \& Doty, P. (1962). Determination of the base composition of deoxyribonucleic acid from its thermal denaturation temperature. J Mol Biol 5, 109-118.

Mora, D., Fortina, M. G., Nicastro, G., Parini, C. \& Manachini, P. L. (1998). Genotypic characterization of thermophilic bacilli: a study on new soil isolates and several reference strains. Res Microbiol 149, 711-722.

Nazina, T. N., Tourova, T. P., Poltaraus, A. B. $\& 8$ other authors (2001). Taxonomic study of aerobic thermophilic bacilli: descriptions of Geobacillus subterraneus gen. nov., sp. nov. and Geobacillus uzenensis sp. nov. from petroleum reservoirs and transfer of Bacillus stearothermophilus, Bacillus thermocatenulatus, Bacillus thermoleovorans, Bacillus kaustophilus, Bacillus thermoglucosidasius and Bacillus thermodenitrificans to Geobacillus as the new combinations G. stearothermophilus, $G$. thermocatenulatus, G. thermoleovorans, G. kaustophilus, G. thermoglucosidasius and G. thermodenitrificans. Int J Syst Evol Microbiol 51, 433-446.

Nystrand, R. (1984). Saccharococcus thermophilus gen. nov., sp. nov., isolated from beet sugar extraction. Syst Appl Microbiol 5, 204-219.

Owen, R. J. \& Hill, L. R. (1979). The estimation of base composition, base pairing and genome sizes of bacterial deoxyribonucleic acid. In Identification Methods for Microbiologists, pp. 277-296. Edited by F. A. Skinner \& D. W. Lovelock. London: Academic Press.

Pettersson, B., Lembke, F., Hammer, P., Stackebrandt, E. \& Priest, F. G. (1996). Bacillus sporothermodurans, a new species producing highly heat-resistant endospores. Int J Syst Bacteriol 46, 759-764.

Rainey, F. A. \& Stackebrandt, E. (1993). Phylogenetic evidence for the relationship of Saccharococcus thermophilus to Bacillus stearothermophilus. Syst Appl Microbiol 16, 224-226.

Rainey, F. A., Fritze, D. \& Stackebrandt, E. (1994). The phylogenetic diversity of thermophilic members of the genus Bacillus as revealed by $16 \mathrm{~S}$ rDNA analysis. FEMS Microbiol Lett 115, 205-212.

Saitou, N. \& Nei, M. (1987). The neighbor-joining method: a new method for reconstructing phylogenetic trees. Mol Biol Evol 4, 406-425.

Salle, A. J. (1961). Laboratory Manual on Fundamental Principles of Bacteriology. New York: McGraw-Hill.

Schumann, P., Prauser, H., Rainey, F. A., Stackebrandt, E. \& Hirsch, P. (1997). Friedmanniella antarctica gen. nov., sp. nov., an LL-diaminopimelic acid-containing actinomycete from Antarctic sandstone. Int $J$ Syst Bacteriol 47, 278-283.

Seidler, R. J. \& Mandel, M. (1971). Quantitative aspects of deoxyribonucleic acid renaturation: base composition, state of chromosome replication, and polynucleotide homologies. $J$ Bacteriol 106, 608-614.

Shida, O., Takagi, H., Kadowaki, K. \& Komagata, K. (1996). Proposal for two new genera, Brevibacillus gen. nov. and Aneurinibacillus gen. nov. Int J Syst Bacteriol 46, 939-946.

Smith, N. R., Gordon, R. E. \& Clark, F. E. (1952). Aerobic Sporeforming Bacteria. Agriculture Monograph 16. Washington, DC: US Dept of Agriculture.

Sunna, A., Tokajian, S., Burghardt, J., Rainey, F., Antranikian, G. \& Hashwa, F. (1997). Identification of Bacillus kaustophilus, Bacillus thermocatenulatus and Bacillus strain HSR as members of Bacillus thermoleovorans. Syst Appl Microbiol 20, 232-237.

Suzuki, Y., Kishigami, T., Inoue, K., Mizoguchi, Y., Eto, N., Takagi, M. \& Abe, S. (1983). Bacillus thermoglucosidasius sp. nov., a new 
species of obligately thermophilic bacilli. Syst Appl Microbiol 4, 487-495.

Touzel, J. P., O'Donohue, M., Debeire, P., Samain, E. \& Breton, C. (2000). Thermobacillus xylanilyticus gen. nov., sp. nov., a new aerobic thermophilic xylan-degrading bacterium isolated from farm soil. Int J Syst Bacteriol 50, 315-320.

Ursing, J. B., Rosselló-Mora, R. A., García-Valdés, E. \& Lalucat, J. (1995). Taxonomic note: a pragmatic approach to the no- menclature of phenotypically similar genomic groups. Int $J$ Syst Bacteriol 45, 604.

Vandamme, P., Pot, B., Gillis, M., De Vos, P., Kersters, K. \& Swings, J. (1996). Polyphasic taxonomy, a consensus approach to bacterial systematic. Microbiol Rev 60, 407-438.

Winker, S. \& Woese, C. R. (1991). A definition of the domains Archaea, Bacteria and Eukarya in terms of small ribosomal RNA characteristics. Syst Appl Microbiol 14, 305-310. 